\title{
COMMENTS
}

\section{Screening for Mutations of 21-Hydroxylase Gene in Hungarian Patients with Congenital Adrenal Hyperplasia*}

\author{
ANNA FERENCZI, MIKLÓS GARAMI, ESZTER KISS, MÓNIKA PÉK, \\ MÁRIA SASVÁRI-SZÉKELY, CSABA BARTA, MÁRIA STAUB, JÁNOS SÓLYOM, AND \\ GYÖRGY FEKETE \\ 2nd Department of Pediatrics (A.F., M.G., E.K., M.P., J.S., G.F.) and Department of Medical \\ Chemistry (M.S.-S., C.B., M.S.), Molecular Biology and Pathobiochemistry, Semmelweis University of \\ Medicine, Budapest, H-1094 Hungary
}

\begin{abstract}
Congenital adrenal hyperplasia $(\mathrm{CAH})$ is a group of autosomal recessive disorders, causing impaired secretion of cortisol and aldosterone from the adrenal cortex, with subsequent overproduction of adrenal androgens. The most common enzyme defect causing $\mathrm{CAH}$ is steroid 21-hydroxylase deficiency. To determine the mutational spectrum in the Hungarian CAH population, the CYP21 active gene was analyzed using PCR. A total of 297 Hungarian patients with 21hydroxylase deficiency are registered in the 2 nd Department of Pediatrics, Budapest, Hungary, and their clinical status was evaluated. Blood samples for CYP21 genotype determination could be obtained
\end{abstract}

from 167 patients (representing 306 unrelated chromosomes and $56.2 \%$ of the total group of patients). Eight of the most common mutations were screened [In2 (intron 2 splice mutation), I172N, Del (Del: apparents large gene conversion), Q318X, R356W, 1761Tins, ClusterE6, V281L] using allele-specific amplification. The most frequent mutation in the Hungarian $\mathrm{CAH}$ population was found to be In2. Our results have shown a good genotype/phenotype correlation in case of most mutations; the In 2 mutation is associated mostly with the severe form of the disease, whereas I172N was expressed in a wide spectrum of phenotypes. (J Clin Endocrinol Metab 84: 2369-2372, 1999)
$\mathrm{C}$ ONGENITAL adrenal hyperplasia (CAH) encompasses a group of genetic disorders of adrenal steroidogenesis $(1,2)$ characterized by impaired activity of one of the enzymes required for cortisol biosynthesis. Steroid-21-hydroxylase deficiency (21-OHD) is present in more than $95 \%$ of the patients with CAH. The incidence of the severe forms is 1 in 15,000 among Caucasians, whereas it seems to be higher for mild forms $(1: 100$ to 1:1000) $(3,4)$. Steroid 21hydroxylase normally converts 17-hydroxyprogesterone into 11-deoxycortisol and progesterone into 11-deoxycorticosterone. These steroids are subsequently converted into cortisol and aldosterone, respectively. Because of accumulation of precursors of the cortisol pathway, 21-OHD causes increased levels of androgens, affecting fetal sex differentiation at an early stage (5).

$\mathrm{CAH}$, resulting from 21-OHD, is a classical monogenic disorder with a very wide range of disease manifestation. This wide spectrum is characterized by severe classical

Received April 27, 1998. Revision received August 27, 1998. Rerevision received March 22, 1999. Accepted March 29, 1999.

Address all correspondence and requests for reprints to: Miklós Garami, 2nd Department of Paediatrics, Semmelweis University of Medicine, Túzoltó utca 7-9., Budapest, H-1094 Hungary. E-mail: miklos@gyer2.sote.hu.

* This work was supported, in part, by Hungarian Screening and Tending Grant OEP 2-01104/95, by the Hungarian National Research Fund (OTKA T 016988), and by the Hungarian Ministry of Welfare (ETT T-11 270/93). forms, with prenatal virilization with or without salt loss, and milder nonclassical forms (NC) that may be asymptomatic or associated with symptoms of androgen excess developing during childhood or at puberty. Affected females should be treated in utero, to reduce virilizing malformations of external genitalia, but this treatment is controversial $(6,7)$. Thus, prenatal diagnosis of 21-OHD is highly desired. Patients with CAH caused by 21-OHD have traditionally been divided into three types: salt-wasting (SW); nonsalt losing or simple virilizing (SV), and late-onset or NC forms. SW form presents with neonatal electrolyte disturbances, together with virilization of external genitalia, at birth in girls, and sexual precocity (because puberty and gonadotropins are not involved in boys). The SV form is similar but without electrolyte disturbances. The NC form lacks the neonatal symptoms and presents with late-onset androgen excess ranging from sexual precocity in childhood to menstrual disturbances, infertility, and hirsutism in adult women. This clinical diversity is shown to result from different mutations in the CYP21 gene, causing varying degrees of enzyme inactivation. These mutations can be deletions, large gene conversions, or point mutations. The adrenal steroid 21-hydroxylase enzyme (also called P450c21) is encoded by two genes: CYP21 and CYP21P (8-10). These genes are located within the human leukocyte antigen class III gene region on the short arm of chromosome 6; both are 3.4-kb long and consist of 10 exons. The CYP21P gene is a so-called pseudogene, with 
no evident function (11). The majority of the mutations in the active steroid 21-hydroxylase gene originate from this highly homologous adjacent pseudogene. The establishment of genotyping of CYP21 gene has been especially challenging, because of the complex structure of the locus.

There has not been any information available on the frequencies of different types of mutations of the active CYP21 gene in the Hungarian population. It is possible that, as a result of several centuries of intermingling foreign populations, the pattern of alterations of the CYP21 gene in Hungary is different from the European pattern. The knowledge of relative frequencies of the point mutations might be useful to delineate appropriate strategies for prenatal diagnoses.

To analyze the mutational spectrum and genotype-phenotype correlation in Hungarian patients with 21-OHD, we investigated the CYP21 gene for the most frequent mutations.

\section{Subjects and Methods}

\section{Patients}

We analyzed the CYP21 active gene in 167 Hungarian patients (patients from 153 families, 14 sibling-pairs, 306 unrelated chromosomes) with steroid 21-hydroxylase deficiency registered in the 2nd Department of Pediatrics, Semmelweis University of Medicine. Clinical classification was based on genital anomalies, the age at presentation, and the hormonal and electrolyte abnormalities.

\section{DNA}

Samples were extracted from peripheral blood leukocytes, as described by Madisen (12). The eight most common mutations were analyzed in the CYP21 gene: Del-apparent large gene conversion, I2 Splice, Ile172Asn, Cluster E6, Leu307insT, Gln318Stop, Arg356Trp, and Val281Leu.

\section{$P C R$}

Allele-specific PCR (ASA) was performed according to the protocol described by Wedell et al.(13), with slight modifications. Initially, samples were analyzed for the presence of an active CYP21 gene, using an allele-specific primer in exon 3 . The samples containing the active gene were further analyzed for the seven most frequent disease-causing, known mutation sites amplifying CYP21 in two separate fragments, i.e. downstream and upstream of the 8-bp deletion site in exon 3. In the first round of PCR, the fragment was amplified; then, in the second round, ASA was performed on the nonpseudogene sequence targeted at the mutation sites. After initial denaturation at $96 \mathrm{C}$ for $3 \mathrm{~min}, 30$ cycles of PCR were done at $96 \mathrm{C}$ for $1 \mathrm{~min}, 54-56 \mathrm{C}$ or $60 \mathrm{C}$ (depending on the primers used) for $30 \mathrm{sec}$, and $72 \mathrm{C}$ for $3 \mathrm{~min}$, in a reaction mixture containing $10 \mathrm{~mm}$ Tris- $\mathrm{HCl}$ ( $\mathrm{pH} 9.0$ at room temperature), $1.5 \mathrm{mmol} / \mathrm{L}$ $\mathrm{MgCl}_{2}, 50 \mathrm{mmol} / \mathrm{L} \mathrm{KCl}, 5 \%$ glycerol, $0.2 \mathrm{mmol} / \mathrm{L}$ deoxynucleotide triphosphate, $1 \mathrm{U}$ of Taq polymerase (Pharmacia Biotech, Uppsala, Sweden), and $0.5 \mu \mathrm{mol} / \mathrm{L}$ of primers except the primer in limiting concentration $(0.15 \mu \mathrm{mol} / \mathrm{L})$. The oligonucleotide primers were as described by Wedell et al. (13) and synthesized by Pharmacia Biosystems. We used $1 \%$ agarose gel electrophoresis $(30 \mathrm{~min}, 12 \mathrm{~V} / \mathrm{cm}$ ) for separation of PCR products, which were visualized by ethidium bromide staining.

Because of the nature of this method, deletions and apparent large gene conversions were not distinguished from each other and are included in the same group. In cases in which no evidence of deletions was detected (we could not obtain samples from the parents of the patients), the samples were designated, for example, $\operatorname{In} 2 / \operatorname{In} 2$ (In2 being the intron 2 splice mutation) or Del. In other words, homozygosity could not be distinguished from hemizygosity.

\section{Results}

The Hungarian CAH registry contains data on 297 patients with 21-OHD, of which 268 individuals are living. Blood samples could be obtained from 167 (62.3\%) of the 268 living patients, including 14 pairs of siblings, representing $153 \mathrm{fam}$ ilies and 306 nonrelated chromosomes. Of the 167 patients, $101(60.5 \%)$ were classified as suffering from the SW form, another 45 (26.9\%) suffered from the SV form, and only 21 $(12.6 \%)$ of the index cases were considered to have the NC form of 21-OHD (Table 1).

Because the sex ratio and clinical spectrum of 21-OHD in the genotyped group were analogous to those in the whole patient group, the total patient population seemed to be well represented by the genotyped patients.

Screening for 8 mutations allows the identification of most of the mutations in $282(92.1 \%)$ out of 306 unrelated chromosomes. Table 2 contains the distribution of different genotypes and the relationships of genotype and phenotype in the Hungarian 21-OHD patients. There are only 12 patients (7\%) whose mutations could not be characterized and 17 patients $(10 \%)$ in whom only one mutated allele was characterized. The most frequent genotypes are the In2/In2 or Del $(30.5 \%)$, the I172N/I172N or Del (10\%), and the Del/Del (9\%).

In the SW form, the most frequent mutations were the In2 and the deletions. In the case of the SV form, the I172N mutation comprised most of the defect; whereas, in the NC form, the most frequent mutation was the V281L. In accordance with the literature $(14,15)$, the In2 mutation in the position of 659 (splice site mutation in intron 2) was found to be the most frequent mutation. All patients in group 0 , predicted to have no enzyme activity, showed the most severe form (SW). Patients with almost complete enzyme impairment, carrying at least one allele with the In2 splicing mutation (with the exception of alleles in category N), presented SW or SV forms. Clinical expression varied in category B. Most of the patients carrying the I172N mutation had the presumed SV form of the disease. At one end of the phenotypic spectrum, there were evident salt wasters. At the other end of the continuum, this group included two patients with homo/hemizygous I172N mutation, presenting with obvious NC 21-OHD. Half of the genotyped NC patients carried the V281L (Group C) mutation.

TABLE 1. Number of patients with 21-hydroxylase deficiency in Hungary

\begin{tabular}{|c|c|c|c|c|c|c|c|c|c|c|}
\hline \multirow{2}{*}{ Type gender } & \multicolumn{3}{|c|}{ SW } & \multicolumn{3}{|c|}{ SV } & \multicolumn{3}{|c|}{$\mathrm{NC}$} & \multirow{2}{*}{ Total } \\
\hline & male & female & $m+f$ & male & female & $\overline{m+f}$ & $\overline{\text { male }}$ & female & $\overline{m+f}$ & \\
\hline Registered & 82 & 76 & 158 & 19 & 50 & 69 & 15 & 55 & 70 & 297 \\
\hline Alive & 65 & 66 & 131 & 17 & 50 & 67 & 15 & 55 & 70 & 268 \\
\hline Dead & 17 & 10 & 27 & 2 & - & 2 & - & - & - & 29 \\
\hline Genotyped & 50 & 51 & 101 & 14 & 31 & 45 & 6 & 15 & 21 & 167 \\
\hline
\end{tabular}


TABLE 2. Genotype categories, exact genotypes, and variation in phenotype

\begin{tabular}{|c|c|c|c|c|c|}
\hline \multirow{2}{*}{ Genotypes } & \multirow{2}{*}{ Group } & \multicolumn{3}{|c|}{ Phenotypes } & \multirow{2}{*}{ Total } \\
\hline & & SW & SV & $\overline{\mathrm{NC}}$ & \\
\hline In2/In2 or Del & $\mathrm{A} / \mathrm{A}$ or $\mathrm{A} / 0$ & 44 & 7 & - & 51 \\
\hline I172N/I172N or Del & $\mathrm{B} / \mathrm{B}$ or $\mathrm{B} / 0$ & 1 & 14 & 2 & 17 \\
\hline $\mathrm{nd} / \mathrm{nd}$ & $\mathrm{N} / \mathrm{N}$ & 4 & 5 & 3 & 12 \\
\hline V281L/V281L or Del & $\mathrm{C} / \mathrm{C}$ or $\mathrm{C} / 0$ & - & - & 8 & 8 \\
\hline In $2 / \mathrm{I} 172 \mathrm{~N}$ or $\operatorname{In} 2+\mathrm{I} 172 \mathrm{~N} / \mathrm{nd}$ & $\mathrm{A} / \mathrm{B}$ or $\mathrm{A} / \mathrm{N}$ & 2 & 6 & - & 8 \\
\hline $\mathrm{I} 172 \mathrm{~N} / \mathrm{nd}$ & $\mathrm{B} / \mathrm{N}$ & - & 4 & 3 & 7 \\
\hline Q318X/Q318X or Del & $0 / 0$ & 5 & - & - & 5 \\
\hline 1761Tins/1761 Tins or Del & $0 / 0$ & 4 & - & - & 4 \\
\hline V281L/nd & $\mathrm{C} / \mathrm{N}$ & 1 & - & 1 & 2 \\
\hline $\mathrm{I} 172 \mathrm{~N} / \mathrm{V} 281 \mathrm{~L}$ or $\mathrm{I} 172 \mathrm{~N}+\mathrm{V} 281 \mathrm{~L} / \mathrm{nd}$ & $\mathrm{B} / \mathrm{C}$ or $\mathrm{B} / \mathrm{N}$ & - & 1 & 1 & 2 \\
\hline V281L + Q318X/V281L + Q318X or Del & $0 / 0$ & 2 & - & - & 2 \\
\hline R356W/nd & $0 / \mathrm{N}$ & - & - & 2 & 2 \\
\hline I172N/R356W or I172N + R356W/nd & $\mathrm{B} / 0$ or $0 / \mathrm{N}$ & 1 & 1 & - & 2 \\
\hline In $2+$ R356W/R356W & $0 / 0$ & 1 & - & - & 1 \\
\hline $\mathrm{In} 2+\mathrm{V} 281 \mathrm{~L}+1761 \mathrm{Tin} \mathrm{s}+\mathrm{R} 356 \mathrm{~W} / \mathrm{In} 2$ & $0 / \mathrm{A}$ & 1 & - & - & 1 \\
\hline In2/1761Tins & $\mathrm{A} / 0$ & 1 & - & - & 1 \\
\hline $\mathrm{In} 2+\mathrm{I} 172 \mathrm{~N} / \mathrm{I} 172 \mathrm{~N}$ & $\mathrm{~A} / \mathrm{B}$ & - & 1 & - & 1 \\
\hline 1761Tins + Q318X/Q318X & $0 / 0$ & 1 & - & - & 1 \\
\hline $\mathrm{In} 2+\mathrm{I} 172 \mathrm{~N} / \mathrm{In} 2$ & $\mathrm{~A} / \mathrm{A}$ & - & 1 & - & 1 \\
\hline V281L + Q318X + R356W/Del & $0 / 0$ & 1 & - & - & 1 \\
\hline $\mathrm{In} 2+\mathrm{I} 172 \mathrm{~N} / \mathrm{In} 2+\mathrm{I} 172 \mathrm{~N}$ or Del & $\mathrm{A} / \mathrm{A}$ or $\mathrm{A} / 0$ & 1 & - & - & 1 \\
\hline V281L/1761Tins or V281L + 1761Tins/nd & $\mathrm{C} / 0$ or $0 / \mathrm{N}$ & - & - & 1 & 1 \\
\hline In $2 / \mathrm{V} 281 \mathrm{~L}$ or $\operatorname{In} 2+\mathrm{V} 281 \mathrm{~L} / \mathrm{nd}$ & $\mathrm{A} / \mathrm{C}$ or $\mathrm{A} / \mathrm{N}$ & - & 1 & - & 1 \\
\hline In2/ClusterE6 or In $2+$ ClusterE6/nd & $\mathrm{A} / 0$ or $0 / \mathrm{N}$ & 1 & - & - & 1 \\
\hline Total & & 101 & 45 & 21 & 167 \\
\hline
\end{tabular}

Enzyme activity: predicted degree of enzyme impairment on type of mutation:

0: $0 \%$ (Del, Q318X, R356W, 1761Tins, ClusterE6)

A: $0-1 \%(\operatorname{In} 2)$

B: $2 \%(\mathrm{I} 172 \mathrm{~N})$

C: $20-50 \%(\mathrm{~V} 281 \mathrm{~L})$

$\mathrm{N}$ : Not-determined enzyme impairment

nd: Not-determined genotype of the allele

\section{Discussion}

The aim of the study was to determine the genotype distribution of the Hungarian CAH patients with 21-OHD. Because of a high amount of ethnic mixing over the centuries in the Hungarian population, it was not possible to assign our patients as a homogenous ethnic group. This is the first report of the Hungarian population-wide screening program for $\mathrm{CAH}$. Until now, this is the largest ongoing study determining CAH patients' genotypes with 21-OHD in CentralEastern Europe.

We screened 167 identified CAH patients in Hungary. This number includes $62.3 \%$ of the living patients of the Hungarian CAH registry. In this present work, we screened 7 of the most common point mutations and deletion (in other words, the absence of the active CYP21 gene) (16). Identifying these mutations, we were able to determine $155(92.8 \%)$ CAH genotypes. However, 12 (7.2\%) genotypes remained unknown. This is not surprising if we consider that the 8 mutations that we analyzed represent $90-92 \%$ of all mutations in the CYP21 gene, according to the literature $(13,16)$. To determine the unknown genotypes, we are performing sequence analysis on their CYP21 genes.
Genetic diagnosis is more complicated for steroid 21-hydroxylase deficiency than for many other monogenic disorders, because of the high variability of the locus. If genotyping is performed without segregation of mutations in families, the linkage phase of mutations in compound heterozygotes can be determined by allele-specific PCR, and the positions of all pseudogene-derived mutations should be analyzed (17). Our present study agrees with the previous results of other nation-wide screening programs $(13,18-23)$.

In some other studies, variation has been detected, and phenotypes are not always correlating with allelic variations in CYP21 gene (24). For example, the In2 mutation manifests with variable clinical symptoms $(25,26)$, whereas all of our patients with In2 as the determining mutation, presented with severe mineralocorticoid deficiency. On the other hand, we found that patients with the I172N mutation revealed clinical variation. This study agrees with the previous results of Jääskeläinen et al. in 1997 (19). The I172N mutation is known to result in clearly reduced enzymatic activity, to about $1-2 \%$ of that found in the wild-type, and it is usually associated with the SV form, although patients with the I172N/deletion genotype with the SW form have been re- 
ported (27). In the present study, the severity of both (SW and SV) mineralocorticoid deficiencies varied excessively; although we formally cannot rule out some additional mutations in CYP21 that might explain the observed clinical heterogeneity.

Certain mutations in CYP21 cause a mild form of the disease that is hard to distinguish from similar, common conditions of unknown etiology. Thus, knowledge about the molecular pathology of 21-OHD may provide a first step toward the understanding of more complex hormonal disorders. The use of PCR advances our knowledge of the mutations causing SW, SV, and NC forms of CAH and is useful in prenatal diagnosis of this disease.

In this study, we screened the entire accessible Hungarian $\mathrm{CAH}$ population, using the ASA technique that was proven to be effective for the rapid identification of the most common mutations in the CYP21 gene (13). However, the present work brought our attention to the limits of this unique technique. Using the ASA method alone, we were not able to determine the exact genotype of the patients without knowing the parents' genotype. To eliminate this problem, we are extending our screening program to the index patients' family, involving mothers and fathers. Having these data at hand, we shall be able to determine the exact genotypephenotype correlation.

\section{Acknowledgments}

The collaboration of the members of the Hungarian CAH Study Group (I. Illyés, J. Kovács, K. Láng, A. Muzsnai, E. Nagy, T. Niederland, G. Soltész, E. Sólyom, and L. Szabó) is acknowledged.

\section{References}

1. White PC, New MI, Dupont B. 1987 Congenital adrenal hyperplasia. N Engl J Med. 316:1519-1524.

2. Newfield RS, New MI. 1997 21-hydroxylase deficiency. Ann NY Acad Sci. 816:219-229.

3. Pang SY, Wallace MA, Hofman L, et al. 1988 Worldwide experience in newborn screening for classical congenital adrenal hyperplasia due to 21-hydroxylase deficiency. Pediatrics. 81:866-874.

4. Therell Jr BL, Berenbaum SA, Manter-Kapanke V, et al. 1998 Results of screening 1.9 million Texas newborns for 21-hydroxylase-deficient congenital adrenal hyperplasia. Pediatrics. 101:583-590.

5. New MI. 1995 Steroid 21-hydroxylase deficiency (congenital adrenal hyperplasia). Am J Med. 98:2S-8S.

6. Speiser PW, New MI. 1994 Prenatal diagnosis and treatment of congenital adrenal hyperplasia. J Pediatr Endocrinol. 7:2263-2266.

7. Seckl JR, Miller WL. 1997 How safe is long-term prenatal glucocorticoid treatment? JAMA. 277:1077-1079.

8. Higashi Y, Yoshioka H, Yamane M, Gotoh O, Fujii-Kuriyama Y. 1986 Complete nucleotide sequence of two steroid 21-hydroxylase genes tandemly arranged in human chromosome: a pseudogene and a genuine gene. Proc Natl Acad Sci USA. 83:2841-2845.
9. White PC, New MI, Dupont B. 1986 Structure of human steroid 21-hydroxylase genes. Proc Natl Acad Sci USA. 83:5111-5115.

10. Rodrigues NR, Dunham I, Yu CY, Carroll MC, Porter RR, Campbell RD. 1987 Molecular characterization of the HLA-linked steroid 21-hydroxylase B gene from an individual with congenital adrenal hyperplasia. EMBO J. 6:1653-1661.

11. Owerbach D, Crawford YM, Draznin MB. 1990 Direct analysis of CYP21B genes in 21-hydroxylase deficiency using polymerase chain reaction amplification. Mol Endocrinol. 4:125-131.

12. Madisen L, Hoar DI, Holroyd CD, Crisp M, Hodes ME. 1987 DNA banking: the effects of storage of blood and isolated DNA on the integrity of DNA. Am J Med Genet. 27:379-390.

13. Wedell A, Thilén A, Stengler B, Ritzén E, Luthman H. 1994 Mutational spectrum of the steroid 21-hydroxylase gene in Sweden: implication for genetic diagnosis and association with disease manifestation. J Clin Endocrinol Metab. 78:1145-1152.

14. Speiser PW, Dupont J, Zhu D, et al. 1992 Disease expression and molecular genotype in congenital adrenal hyperplasia due to 21-hydroxylase deficiency. J Clin Invest. 90:584-595.

15. Carrera P, Bordone L, Azzani T, et al. 1996 Point mutations in Italian patients with classic, nonclassic, and cryptic forms of steroid 21-hydroxylase deficiency. Hum Genet. 98:662-665.

16. Mornet E, Crété P, Kuttenn F, et al. 1991 Distribution of deletions and seven point mutations on CYP21B genes in three clinical forms of steroid 21-hydroxylase deficiency. Am J Hum Genet. 48:79-88.

17. Wedell A, Luthman H. 1993 Steroid 21-hydroxylase: a new allele and spread of mutations through the pseudogene. Hum Genet. 91:236-240.

18. Ginalska-Malinowska M, Romer TE, Borucka-Mankiewicz M, Popowska E. 1996 Detection of mutations in the steroid 21-hydroxylase gene in Polish patients with 21-hydroxylase deficiency. Horm Res. 46 [Suppl 2]:118 (Abstract 469).

19. Jääskeläinen J, Levo A, Voutilainen R, Partanen J. 1997 Population-wide evaluation of disease manifestation in relation to molecular genotype in steroid 21-hydroxylase (CYP21) deficiency: good correlation in a well defined population. J Clin Endocrinol Metab. 82:3293-3297.

20. Dardis A, Bergada I, Bergada C, Rivarola M, Belgorosky A. 1997 Mutations of the steroid 21-Hydroxylase gene in an Argentinian population of 36 patients with classical congenital adrenal hyperplasia. J Pediatr Endocrinol Metab. 10:55-61.

21. Balsamo A, Baroncini C, Baldazzi L, et al. 1996 Mutational spectrum of the CYP21B gene in the CAH patients of the Emilia-Romagna region (years 1980 1995). Horm Res. 46 [Suppl 2]:118 (Abstract 467).

22. Ezquieta B, Oliver A, Gracia R, Gancedo PG. 1995 Analysis of steroid 21hydroxylase gene mutations in the Spanish population. Hum Genet. 96:198-204.

23. Dracopoulou M, Dacou-Voutetakis C. 1996 Molecular genotype in congenital adrenal hyperplasia $(\mathrm{CAH})$ due to 21 hydroxylase $(21 \mathrm{OH})$ deficiency in Hellelic population. Relation to phenotype. Horm Res. 46 [Suppl 2]:118 (Abstract 470).

24. Wilson RC, Mercado AB, Cheng KC, New MI. 1995 Steroid 21-hydroxylase deficiency: genotype may not predict phenotype. J Clin Endocrinol Metab. 80:2322-2329.

25. Witchel SF, Bhamidipati DK, Hoffman EP, Cohen JB. 1996 Phenotypic heterogeneity associated with the splicing mutation in congenital adrenal hyperplasia due to 21-hydroxylase deficiency. J Clin Endocrinol Metab. 81:4081-4088.

26. Rumsby G, Massoud AF, Avey C, Brook CGD. 1996 Nonexpression of a common mutation in the 21-hydroxylase gene: implications for prenatal diagnosis and carrier testing. J Med Genet. 33:798-799.

27. Chiou SH, Hu MC, Chung BC. 1990 A missense mutation at Ile172Asn or Arg356Trp causes steroid 21-hydroxylase deficiency. J Biol Chem. 265:35493552 . 